признаки метастазирующих папиллярных микрокарцином щитовидной железы / И.В. Ивахно // Вісник проблем біології і медицини. 2014. - Т. 3, №. 4. - С. 266-269.

2. Папиллярная микрокарцинома щитовидной железы / В.А. Смирнова, Г.В. Семкина, Н.М. Платонова, В.Э. Ванушко // Клиническая и экспериментальная тиреоидология. - 2015. - Т. 11, №. 2. - С. 11-24.

Дата надходження до редакиії 18.10.2018 p.
3. Leenhardt $L$. Increased incidence of thyroid carcinoma in France: a true epidemic or thyroid nodule management effects? Report from the French Thyroid Cancer Committee / L. Leenhardt, P. Grosclaude, L. Chérié-Challine // Thyroid. - 2004. Vol. 14, N. 12. - P. 1056-1060.

https://doi.org/10.24026/1818-1384.4(64).2018.150163

\title{
КЛІНІКО-ПАРАКЛІНІЧНІ ХАРАКТЕРИСТИКИ АНДРОГЕНОВОГО ДЕФІЦИТУ У ЖІНОК РЕПРОДУКТИВНОГО ВІКУ
}

\author{
Л.В. Дем'яненко \\ Український науково-практичний иентр ендокринної хірургії, \\ трансплантації ендокринних органів і тканин МОЗ України.
}

Не дивлячись на те, що дотепер не існує «золотого стандарту» для виявлення андрогенового дефіциту в клінічній практиці, дослідження в цьому напрямку проводяться. Європейська ендокринологічна спільнота вважає, що ці заходи необхідні для виявлення прийнятного з клінічної точки зору визначення, що відповідає синдрому дефіциту андрогенів у жінок, які були 6 основані на вимірюваних параметрах андрогенів і конкретних клінічних проявах жіночої андрогенової недостатності.

Мета: виявити клінічні характеристики недостатності андрогенів у жінок репродуктивного віку.

Матеріали і методи. Нами обстежено 80 жінок репродуктивного віку, що мали основні скарги на сексуальні порушення (зниження лібідо та відсутність оргазму, а також диспареунію) і 30 здорових жінок репродуктивного віку без скарг на розлади в сексуальному здоров'ї. Використовували метод анкетування пацієнтів з детальним вивченням соціально-економічного статусу, соматичного, гінекологічного, акушерського та сексуального анамнезу, загальноклінічний та гінекологічний огляд.

Результати і обговорення. Важливість андрогенів для організму людини пояснюється знаходженням андрогенових рецепторів у клітинах більшості тканин: молочної залози, серця, кровоносних судин, шлунково-кишкового тракту (ШКТ), легень, ЦНС і периферичних нервах, шкірі, кістково-м'язовому апараті, кістковому мозку, матці, яєчниках, зовнішніх статевих органах, жировій тканині. Проаналізувавши дані анкетування та загальноклінічного і гінекологічного оглядів, та виключивши пацієнток 3 соматичною та гінекологічною патологією, ми виявили, що дефіцит андрогенів у жінок проявлявся сексуальними порушеннями у 100\% (80 пацієнток) основної групи (зниженням лібідо, порушенням сексуального задоволення та відсутністю оргазму). Також виявили інші патологічні симптоми, включаючи зміни настрою (дратівливість, тривожність, депресія) у 80\% (64 пацієнтки) основної групи, в той час як в контрольній групі лише у $20 \%$ (6 жінок). Скарги на погане самопочуття, швидку втомлюваність, слабкість були характерними для $67 \%$ (54) жінок основної групи і 20\% (6) - контрольної. Порушення пам'яті та когнітивних функцій відзначали 56\% (45) пацієнток основної групи і 17\% (5) контрольної. Порушення сечовипускання, в тому числі нетримання сечі, не пов'язані з органічною патологією сечовивідних шляхів, діагностовано у 49\% (39) жінок основної і 4\% (1) контрольної групи. Відомі ефекти андрогенів на стан м'язів тазового дна та слизових оболонок зовнішніх статевих органів у жінок. У нашому дослідженні було виявлено атрофічні зміни слизової оболонки піхви та екзоцервіксу у 70\% (56) жінок основної групи і 
пролапс геніталій легкого чи середнього ступеню у 32\% (27), в той час як в контрольній групі даної патології не виявлено.

Висновки. Виявлені патологічні стани у жінок репродуктивного віку можуть бути свідченням порушення синергічної взаємодії андрогенів 3 естрадіолом, яка вкрай необхідна для забезпечення повноцінних фізіологічних ефектів в цілісному організмі жінки, тому будь-які порушення синтезу та метаболізму андрогенів можуть мати негативні наслідки для багатьох складових жіночого здоров'я і для якості життя в цілому. Тому в спілкуванні 3 пацієнтами слід звертати увагу і на такі скарги, як сексуальні порушення, зміни настрою, погане самопочуття та фізична слабкість, порушення пам'яті, розлади сечовипускання та ознаки атрофічних змін нижніх відділів генітального тракту жінок в репродуктивному віці.

\section{ЛІТЕРАТУРА}

1. Bosdou JK, Venetis CA, Kolibianakis EM, et al. The use of androgens or androgen-modulating agents in poor responders undergoing in vitro fertilization: a systematic review and meta-analysis. Hum Reprod Update. 2012 Mar-Apr; 18(2):127-45.

2. Nappi R. Androgens and postmenopausal sexuality. Proceedings 8th European congress of menopause. London, UK, May 16-20, 2009, p. S10.

3. Kalinchenko SYu, Tyuzikov IA, Grekov EA, Apetov SS, Vorslov LO, Tishova Y.A. [Androgens and lower urinary tract symptoms: only male gender or unsolved problems of both sexes?] Eksperimentalnaya i Klinicheskaya Urologiya. 2013; (4):40-48. [Russian].

Дата надходження до редакції 26.10.2018 p.

https://doi.org/10.24026/1818-1384.4(64).2018.150164

\title{
ЗВ'ЯЗОК ГІПЕРПРОЛАКТИНЕМІЇ З АНЕМІЄЮ У ХВОРИХ НА ХРОНІЧНУ ХВОРОБУ НИРОК БД СТАДІЇ
}

\author{
І.О. Дудар, В.М. Савчук, І.М. Шіфріс, О.М. Лобода, Ю.І. Гончар \\ ДУ «Інститут нефрологї НАМН України»
}

Кількість пацієнтів, які лікуються нирковозамісною терапією (НЗТ), у світі щорічно зростає. Незважаючи на прогрес у лікуванні хронічної хвороби нирок (XXH), багато метаболічних та ендокринних розладів, пов'язаних 3 хронічною уремією, залишаються невирішеними.

Поширеність гіперпролактинемії у хворих на XXH становить від 30\% до 65\%. За умови XXН продукція та елімінація пролактину (ПЛ) змінюються. Відмічають негативну кореляцію між швидкістю клубочкової фільтрації (ШКФ) та рівнем ПЛ, індексом маси тіла (IMT) та ПЛ, рівнем фосфору і кальцію та ПЛ, а також між низьким рівнем альбуміну і гемоглобіну та ПЛ.

Мета: Визначити зв'язок рівнів пролактину 3 частотою анемії та рівнем серцево-судинних подій у хворих на ХХН 5Д стадії.

Матеріали та методи. У проспективне когортне дослідження включено 55 хворих на XXH VД стадії 3 анемією, які отримують лікування гемодіалізом (ГД) у Київському міському науково-практичному центрі нефрології та діалізу, що $є$ клінічною базою
ДУ «Інститут нефрології НАМН України». Середній вік пацієнтів становив 51,4 $\pm 11,5$ року. 3 загального числа обстежених жінок було 35 (63,6\%) та чоловіків - 20 (36,4\%). Окрім стандартних методів дослідження всім хворим визначався рівень пролактину сироватки крові.

Результати. 24 пацієнти (44\%) мали рівні ПЛ

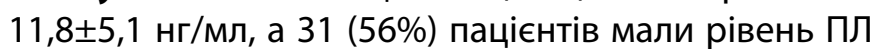

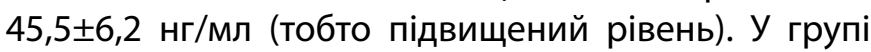
3 підвищеним рівнем ПЛ анемія реєструвалася достовірно частіше, ніж у пацієнтів 3 нормальним рівнем ПЛ (р <0,01) при дозі еритропоезстимулювальних препаратів 50 ОД/кг/тиждень.

Частота серцево-судинних подій у пацієнтів 3 підвищеним рівнем ПЛ була достовірно вищою, ніж у пацієнтів з нормальним рівнем ПЛ ( $p<0,01)$.

Висновки. Визначення рівня пролактину має важливе значення, оскільки цей гормон $\epsilon$ предиктором збільшення смертності, в тому числі, серцево-судинної, прогресування атеросклерозу, виникнення гонадальної дисфункції, гінекомастії, 